\title{
Perlindungan Musytari Terhadap Klausula Baku Dalam Pembiayaan Murabahah Bil Wakalah PT. Bank BRI Syariah, Tbk.
}

\author{
Valeria Zahara Zulkarnaen \\ Magister Kenotarian Fakultas Hukum Universitas Islam Indonesia \\ Jln. Cik Di Tiro Nomor 1, Yogyakarta \\ valeriazahara16@gmail.com
}

\begin{abstract}
This research examines the existence of a clause in the Murabahah bil Wakalah contract at a bank which states that if based on the bank's assessment the collateral is no longer sufficient to guarantee debt payment, Musytari is obliged to add other items as collateral. Therefore, two problems arise: first about the legality of the clause; and second, the role of the notary in enforcing the implementation of the taswiyah principle in the Murabahah bil Wakalah contract. This type of research is normative and empirical, with literature and document studies, along with interviewing sources, and analyzed through a statutory approach, with qualitative methods. The results of the study conclude, first, the clause of adding collateral by the bank to Musytari is not in accordance with one of the pillars of the contract, namely Taswiyah, but is still legal as it is made in the presence of a notary; second, the role of a notary in the Murabahah bil Wakalah contract is to provide legal counseling to Musytari if the bank requires additional collateral to be fulfilled.
\end{abstract}

Key Words: Legal protection of musytari; murabahah bil wakalah; standard clause

\begin{abstract}
Abstrak
Penelitian ini mengkaji adanya klausula dalam akad Murabahah bil Wakalah pada bank yang menyatakan apabila berdasarkan penilaian bank jaminan tidak lagi cukup untuk menjamin pembayaran hutang, Musytari wajib menambahkan barang lainnya sebagai jaminan. Oleh karena itu, muncul dua masalah: pertama tentang legalitas klausul tersebut; dan kedua, peran notaris dalam menegakkan pelaksanaan prinsip taswiyah dalam akad Murabahah bil Wakalah. Jenis penelitian yang digunakan bersifat normatif dan empiris, dengan studi pustaka dan dokumen, disertai wawancara narasumber, dan dianalisa melalui pendekatan undang-undang, dengan metode kualitatif. Hasil penelitian menyimpulkan, pertama, klausula penambahan jaminan oleh bank kepada Musytari tidak sesuai dengan salah satu rukun akad yaitu Taswiyah, namun tetap legal karena dibuat di hadapan notaris; kedua, peranan notaris dalam akta Murabahah bil Wakalah yakni memberi penyuluhan hukum kepada Musytari apabila bank menghendaki jaminan tambahan harus dipenuhi
\end{abstract}

Kata-kata Kunci: Klausula baku; murabahah bil wakalah; perlindungan hukum musytari 


\section{Pendahuluan}

Indonesia adalah sebuah negara kepulauan yang memiliki keragaman etnis, budaya, dan agama. Salah satu contohnya adalah agama Islam, yang berpedoman pada Al-Qur'an dan Hadits. Realitas dalam masyarakat, tidak sedikit yang menganggap bahwa hukum agama khususnya hukum Islam hanya digunakan dalam hal ritual ibadah saja. Padahal, agama Islam telah memberikan pengaturannya secara komprehensif, menyangkut semua aspek dalam kehidupan manusia termasuk dalam lapangan muamalah. ${ }^{1}$

Beriringan tidak sedikitnya anggapan bahwa hukum Islam hanya digunakan dalam hal ritual ibadah saja, disisi lain terdapat minat masyarakat untuk mempelajari sistem ekonomi Islam semakin meningkat. Bahkan sejak disahkannya kedua undang-undang ini yaitu Undang-Undang Nomor 7 Tahun 1992 tentang Perbankan Syariah dan Undang-Undang Nomor 10 Tahun 1998 tentang perubahan atas Undang-Undang Nomor 7 Tahun 1992 tentang Perbankan, yang setidaknya dijadikan sebagai legalitas dalam pengelolaan usahanya, dalam undang-undang tersebut bank terdiri dari Bank Konvensional dan Bank Syariah. Khusus untuk bank syariah ini terdiri dari Bank Umum Syariah dan Bank Pembiayaan Rakyat Syariah², di Indonesia mulai berdiri bankbank syariah, baik yang secara khusus mendasarkan pengelolaannya secara syariah murni ataupun bank-bank konvensional yang membuka jendela syariah (islamic window) dalam usaha perbankan yang dijalankannya. Berdiri pula lembaga-lembaga keuangan Islam yang lain, seperti, Baitul Mal wa Tamwil (BMT), juga ada lembaga Asuransi Syariah (Takaful). ${ }^{3}$

Pengelolaan usaha dengan beraneka ragam produk dalam Bank Islam di dasarkan pada perjanjian dengan Musytarinya, konsep perjanjian dengan Musytari dalam agama Islam ini memegang peran yang penting. ${ }^{4}$ Dalam konteks hukum Barat, Pasal 1313 KUHPerdata menyebutkan yang dimaksud dengan perjanjian adalah suatu perbuatan dengan mana satu orang atau lebih mengikatkan dirinya terhadap orang lain, satu orang atau lebih. ${ }^{5}$

Setiap perjanjian agar secara sah mengikat bagi para pihak-pihak yang mengadakan harus memenuhi syarat sahnya perjanjian, yang secara khusus hlm. 3 .

${ }^{1}$ Abdul Ghofar Anshori, Pokok-pokok. Hukum Perjanjian Islam di Indonesia, Citra Media, Yogyakarta, 2006,

${ }^{2}$ Ibid., hlm. 4.

${ }^{3}$ Ibid., hlm. 5.

${ }^{4}$ Ibid., hlm. 6.

${ }^{5}$ Kartini Muljadi dan Gunawan Widjaja, Perikatan yang Labir dari Perjanjian, RajaGrafindo Persada, Jakarta, 2004, hlm. 7 . 
diatur dalam ketentuan Pasal 1320 KUHPerdata, yaitu perlunya adanya kesepakatan para pihak (asas konsensual), kecakapan bertindak dari para pihak, adanya objek tertentu, dan mempunyai kausa yang halal. Tidak ada kesepakatan kalau di dalamnya terdapat paksaan (dwang), kekhilafan (dwaling), maupun penipuan (bedrog). Ketentuan Pasal 1330 KUHPerdata disebutkan mengenai siapa yang oleh hukum dianggap tidak cakap, yaitu anak yang masih di bawah umur, orang yang hilang ingatan (ditaruh di bawah pengampuan), orang yang boros dan istri dari suami yang tunduk pada KUHPerdata. Mereka dalam bertindak harus diwakili oleh orang tua, wali atau kuratornya. ${ }^{6}$

Objek perjanjian harus tertentu atau minimal dapat ditentukan selain itu segala sesuatu yang menjadi objek perjanjian tidak boleh bertentangan dengan Undang-Undang, kesusilaan, maupun ketertiban umum yang berlaku di masyarakat. Bahwa suatu perjanjian yang dibuat dilarang tanpa sebab, memuat sebab palsu, ataupun sebab yang dilarang. Konsekuensi yuridis jika salah satu syarat tidak dapat dipenuhi adalah kebatalan dari perjanjian yang bersangkutan, baik dapat dibatalkan maupun batal demi hukum. Sedangkan konsekuensi yuridis dari perjanjian yang sah adalah mengikat bagi para pihak laksana Undang-Undang (vide Pasal 1338 KUHPerdata) di samping itu juga menjadikan para pihak wajib melaksanakannya dengan itikad baik dan tidak bisa memutuskan perjanjian tersebut secara sepihak. ${ }^{7}$

Penggunaan kontrak baku dalam perjanjian di dunia bisnis dewasa ini sangat menguntungkan pengusaha, namun di sisi lain menimbulkan kerugian bagi konsumen. ${ }^{8}$ Hal ini dapat dilihat dari kebiasaan para pelaku usaha untuk menutup suatu transaksi dengan terlebih dahulu telah menyiapkan formatformat kontrak yang umumnya telah tercetak (modelled draft of contract) untuk ditandatangani oleh mitra berkontraknya. Hal itu telah menghilangkan atau paling tidak telah membatasi kebebasan berkontrak (freedom of contract) dari mitra berkontraknya untuk secara seimbang dapat menegoisasikan isi kesepakatan yang dapat diterimanya. ${ }^{9}$ Kebiasaan ini lah yang menciderai asas-asas universal yang berlaku dalam hukum kontrak yaitu asas kebebasan berkontrak, asas kebebasan memilih hukum yang berlaku, dan asas kebebasan menentukan yurisdiksi.

${ }^{6}$ Abdul Ghofar, Op. Cit., hlm. 7.

${ }^{7}$ Ibid, hlm. 8.

8 Ridwan Khairandy, "Keabsahan Perjanjian Standar Pasca Berlakunya Undang-Undang Perlindungan Konsumen”, Makalah, Yogyakarta, 2007, hlm. 1.

${ }_{9}$ Ricardo Simanjuntak, "Akibat dan Tindakan-tindakan Hukum terhadap Pencantuman Klausula Baku Dalam Polis Asuransi yang Bertentangan dengan Pasal 18 Undang-Undang Nomor 8 Tahun 1999 tentang Perlindungan Konsumen", Jurnal Hukum Bisnis, Vol.22, No. 2, 2003, hlm. 53. 
Mengenai penerapan asas kebebasan berkontrak sepenuhnya tergantung pada para pihak untuk menentukan pilihannya, akan tetapi ada pihak lain yang dapat menjaga rambu-rambu hukumnya, yaitu Notaris. ${ }^{10}$

Berdasarkan hasil penelusuran kasus, terdapat Akad Pembiayaan Murabahah bil Wakalah PT. Bank BRI Syariah Tbk, yang klausula perjanjiannya menyatakan bahwa apabila berdasarkan pertimbangan bank, nilai dari barang-barang jaminan sebagaimana dimaksud dalam dokumentasi jaminan tidak lagi cukup untuk menjamin pembayaran kewajiban atau hutang Musytari (Nasabah) kepada bank, Musytari wajib menambah barang jaminan lainnya yang disetujui bank. Klausula ini oleh Musytari dianggap memberatkan seiring berjalannya proses pembiayaan tersebut. Tanpa memahami seperti apa standar pertimbangan bank sehingga Musytari diwajibkan untuk menambah barang jaminan lainnya. Pada penelitian ini, penulis secara eksplisit akan mengkaji hal tersebut berdasarkan ketentuan dari asas taswiyah, dimana asas tersebut mengatur tentang kesetaraan para pihak.

\section{Rumusan Masalah}

Berdasarkan uraian tersebut di atas, adapun permasalahan yang diangkat dalam penelitian ini sebagai berikut: pertama, bagaimana legalitas klausula yang mengharuskan Musytari untuk menambah objek jaminan (berdasarkan pertimbangan bank) pada akad murabahah bil wakalah? Kedua, bagaimana peranan notaris dalam menjamin penerapan asas taswiyah pada akad pembiayaan murabahah bil wakalah PT. Bank BRI Syariah, Tbk?

\section{Tujuan Penelitian}

Penelitian ini bertujuan: pertama, untuk mengetahui legalitas klausula yang mengharuskan Musytari untuk menambah objek jaminan (berdasarkan pertimbangan bank) pada akad murabahah bil wakalah. Kedua, untuk mengetahui peranan notaris dalam menjamin penerapan asas taswiyah pada akad pembiayaan murabahah bil wakalah PT. Bank BRI Syariah, Tbk.

\section{Metode Penelitian}

Penelitian dengan judul "Perlindungan Musytari Terhadap Klausula Baku dalam Pembiayaan Murabahah Bil Wakalah PT. Bank BRI Syariah Tbk." adalah merupakan penelitian hukum normatif atau penelitian kepustakaan, yakni merupakan penelitian yang mengkaji studi dokumen, yakni menggunakan

\footnotetext{
${ }^{10}$ Rusdianto Sesung, Hukum dan Politik Hukum Jabatan Notaris, R.A. De Rozarie, Surabaya, 2017, hlm. 63.
} 
berbagai data sekunder seperti peraturan PerUndang-Undangan, teori hukum, dan dapat berupa pendapat para sarjana. Penelitian jenis normatif ini menggunakan analisis kualitatif yakni dengan menjelaskan data-data yang ada dengan kata-kata atau pernyataan bukan dengan angka-angka. Objek penelitian ini adalah semua pihak yang terkait dan berhubungan dengan masalah penelitian ini, yang terdiri dari: a. Undang-Undang Dasar Republik Indonesia Tahun 1945; b. KUH-Perdatap; c. Undang-Undang Perbankan Syariah; d. Kompilasi Hukum Ekonomi Syariah

Penelitian ini juga merupakan penelitian hukum empiris, yakni suatu metode penelitian hukum yang menggunakan fakta-fakta empiris yang diambil dari perilaku manusia, baik perilaku verbal yang di dapat dari wawancara maupun perilaku nyata yang dilakukan melalui pengamatan langsung. Penelitian empiris juga digunakan untuk mengamati hasil dari perilaku manusia yang berupa peninggalan fisik maupun arsip. Objek penelitian ini adalah semua pihak yang terkait dan berhubungan dengan masalah penelitian ini, yang terdiri dari : a. Bank Bri Syariah; b. Musytari Bank BRI Syariah.

\section{Hasil Penelitian dan Pembahasan}

Legalitas Klausula yang Mengharuskan Musytari untuk Menambah Objek Jaminan (Berdasarkan Pertimbangan Bank) pada Akad Murabahah Bil Wakalah

Istilah Murabahah memiliki arti pembelian barang dengan pembayaran ditangguhkan, pembiayaan murabahah merupakan pembiayaan yang diberikan kepada Musytari dalam rangka pemenuhan kebutuhan produksi (inventory). Pembiayaan murabahah mirip dengan kredit modal kerja yang biasa diberikan oleh bank-bank konvensional, dan karenanya pembiayaan murabahah berjangka waktu dibawah 1 (satu tahun). ${ }^{11}$ Dari penjelasan tersebut, Murabahah merupakan suatu akad jual beli yang dilakukan kepada seseorang, dimana penjual menyampaikan harga beli kepada pembeli dan keuntungan yang diambil sesuai dengan kesepakatan kedua belah pihak.

Pada perbankan syariah, diwajibkan adanya suatu barang yang diperjual belikan tersebut berupa harta yang jelas harganya, seperti mobil atau motor. Sedangkan akad kredit perbankan konvensional terhadap konsumen berupa akad pinjam meminjam yang dalam ini belum tentu ada barangnya12 Murabahah dikatakan sah hanya ketika biaya-biaya perolehan barang dapat ditentukan secara pasti. Jika biaya-biaya tidak dapat dipastikan, barang atau komoditas tersebut

${ }^{11}$ Karnaen Perwataatmadja dan Muhammad Syafi'i Antonio, Apa dan Bagaimana Bank Islam, Dana Bhakti Wakaf, Yogyakarta, 1992, hlm. 25.

12 Binti Nur Asiyah, Manajemen Pembiayaan Bank Syariah, Teras, Yogyakarta, 2014, hlm. 224. 
tidak dapat dijual dengan prinsip murabahah. ${ }^{13}$ Barang dalam perjanjian in wajib untuk di pastikan.

Istilah Wakalah secara bahasa memiliki arti menyerahkan sesuatu. Dalam istilah syara" berarti seseorang yang menyerahkan sesuatu urusannya kepada orang lain, pada apa yang boleh diwakilkan menurut syara", agar orang yang mewakilkan itu dapat melakukan sesuatu yang diserahkan kepadanya selagi yang menyerahkan itu masih hidup. Perwakilan sah dilakukan pada permasalahan jual beli, kawin, talak, memberi, menggadai dan suatu barang yang berhubungan dengan muamalah. ${ }^{14}$ Dalam hal ini wakalah merupakan suatu pelimpahan kuasa ke orang lain untuk melakukan suatu hal tertentu.

Terdapat beberapa syarat dalam akad Syariah yaitu ${ }^{15}$ Pertama, kedua orang yang melakukan akad cakap bertindak (ahli). Tidak sah akad orang yang tidak cakap bertindak, seperti pengampuan, dan karena boros. Kedua, yang dijadikan objek akad dapat menerima hukumnya. Ketiga, akad itu di izinkan oleh syara", di lakukan oleh orang yang mempunyai hak melakukannya, walaupun dia bukan aqid yang memiliki barang. Keempat, janganlah akad itu akad yang di larang oleh syara", seperti jual beli mulasamah. Akad dapat memberikan faedah, sehingga tidaklah sah bila rahn (gadai) di anggap sebagai imbalan amanah (kepercayaan). Kelima, ijab itu berjalan terus, tidak di cabut sebelum terjadi qabul. Maka apabila orang berijab menarik kembali ijabnya sebelum qabul maka batallah ijabnya. Keenam, ijab dan qabul harus bersambung, sehingga bila seseorang yang berijab telah berpisah sebelum adanya qabul, maka ijab tersebut menjadi batal.

Syarat Sah Perjanjian dalam Suatu perjanjian yang sah adalah perjanjian yang memenuhi syarat-syarat yang diatur oleh Undang-Undang. Perjanjian tersebut diakui sah dan mendapat akibat hukum (legally concluded contract). Menurut ketentuan Pasal 1320 KUHPerdata, syarat-syarat sah perjanjian adalah ${ }^{16}$ Pertama, ada persetujuan kehendak (consensus). Kedua, kecakapan pihak-pihak untuk membuat perjanjian (capacity). Kecakapan bertindak merupakan salah satu cakap hukum yaitu kemampuan untuk melakukan perbuatan hukum. Orang yang dikatakan cakap melakukan perbuatan hukum adalah orang yang sudah dewasa artinya sudah mencapai umur 21 tahun atau sudah kawin walaupun belum berumur 21 tahun. Sedangkan orang yang tidak cakap untuk melakukan

13 Ascarya, Akad \& Produk. Bank Syariah, RajaGrafindo Persada, Jakarta, 2008, hlm. 84.

${ }^{14}$ Idris, Fiqh Menurut Madz̧ab Syafi'i, Widjaya, Jakarta, 1969, hlm. 67.

15 Abdul Rahman Ghazaly, Fiqh Muamalat, Kencana, Jakarta, 2010, hlm. 55.

16 Abdulkadir Muhammad, Hukum Perdata Indonesia, Cetakan Ke-III, Citra Aditya Bakti, Bandung, 2000, hlm. 228. 
perbuatan hukum ${ }^{17}$ adalah orang-orang yang belum dewasa; Mereka yang ditaruh di bawah pengampunan; dan Orang-orang perempuan, dalam hal-hal yang ditetapkan oleh undang-undang, dan pada umumnya semua orang kepada siapa Undang-Undang telah melarang membuat perjanjian-perjanjian tertentu. (ketentuan ini telah dicabut oleh Surat Edaran Mahkamah Agung). Akibat hukum ketidakcakapan membuat perjanjian adalah perjanjian yang telah dibuat dapat dimintakan pembatalan perjanjian kepada Hakim. Jika tidak dimintakan pembatalan maka perjanjian tersebut tetap berlaku bagi para pihak yang terkait dengan perjanjian tersebut.

Ketiga, ada suatu hal tertentu (objek). Suatu hal tertentu yang terdapat dalam isi perjanjian yang wajib dipenuhi/prestasi disebut sebagai objek perjanjian. Keempat, ada suatu sebab yang halal (causa) Causa atau sebab adalah suatu hal yang menyebabkan/mendorong orang untuk membuat perjanjian. Menurut KUHPerdata Pasal 1335 disebutkan bahwa "suatu perjanjian tanpa sebab, atau yang telah dibuat karena suatu sebab yang palsu atau terlarang, tidak mempunyai kekuatan". Tetapi dalam Pasal 1336 KUH Perdata disebutkan "jika tidak dinyatakan suatu sebab, tetapi ada sebab yang halal, ataupun jika ada suatu sebab lain, dari pada yang dinyatakan, perjanjianya namun demikian adalah sah". Sebab yang halal menurut Pasal 1337 KUHPerdata adalah sebab yang tidak dilarang oleh undang-undang, tidak berlawanan dengan kesusilaan ataupun ketertiban umum. ${ }^{18}$

Dalam akad Murabahah bil wakalah semua pihak baik Lembaga Keuangan Syariah maupun Musytari wajib tunduk dan taat pada semua aturan hukum islam yang sudah di tentukan. Dalam rukun murabahah bil wakalah terdapat wakil dalam pembelian barang, rukun dalam akad tersebut, ${ }^{19}$ yaitu Penjual ( $\left.b a^{\prime} i\right)$; Pembeli (musytari); Barang yang dibeli; Harga barang, dalam hal ini harga barang harus diketahui secara jelas yaitu harga beli dan margin yang akan disepakati oleh kedua belah pihak. Sehingga kedua belah pihak akan melakukan keputusan harga jual dan jangka waktu pengangsuran; Muwakil atau pemberi kuasa adalah pihak yang memberikan kuasa kepada pihak lain; Taukil atau objek akad; Shigat atau ijab dan Qabul

Sedangkan syarat-syarat dari akad murabahah bil wakalah, ${ }^{20}$ yaitu Barang yang diperjual belikan harus halal dan bebas dari najis; Penjual memberitahu modal yang akan diberikan kepada Musytari; Kontrak pertama harus sah sesuai

${ }^{17}$ R. Subekti dan R. Tjitrosudibio. Kitab Undang-undang Hukum Perdata, Cetakan ke-37, Pradnya Paramita, Jakarta, 2006, hlm. 341.

${ }^{18}$ Ibid., hlm 342.

${ }^{19}$ Binti Nur Asiyah, Op. Cit., hlm. 224

${ }^{20}$ Ibid. 
dengan rukun yang telah ditetapkan; Kontrak harus bebas dari riba; Penjual harus memberitahu atau menjelaskan bila terjadi cacat atas barang sesudah pembelian; Penjual harus menyampaikan semua hal yang berkaitan dengan pembelian, misalnya jika pembelian tersebut dilakukan secara utang; Objek barang yang akan dibeli harus jelas dan diwakilkan kepada Musytari yang mengajukan pembiayaan dengan akad murabahah bil wakalah; Tidak bertentangan dengan syariat islam.

Dalam kasus tersebut juga semua pihak wajib memperhatikan beberapa asas dalam perjanjian, salah satunya adalah asas kebebasan berkontrak. Sutan Remy Sjahdeini menjelaskan bahwa asas kebebasan berkontrak menurut hukum kontrak di Indonesia meliputi kebebasan untuk membuat atau tidak membuat kontrak, kebebasan untuk memilih pihak, kebebasan menentukan cause, kebebasan untuk menentukan objek kontrak, kebebasan menentukan bentuk suatu kontrak, kebebasan untuk menerima atau menyimpangi ketentuan undangundang yang bersifat opsional. ${ }^{21}$

Asas lain dari perjanjian mengenai kasus tersebut yaitu Asas pacta sunt servanda, Asas yang termuat dalam Pasal 1338 ayat (1) KUHPerdata, yang berbunyi "semua perjanjian yang dibuat secara sah berlaku sebagai UndangUndang bagi yang mereka yang membuatnya". Dengan menekankan pada perkataan semua, maka Pasal tersebut seolah-olah berisikan suatu pernyataan kepada masyarakat bahwa kita diperbolehkan membuat perjanjian yang berupa dan berisi apa saja atau tentang apa saja dan perjanjian itu akan mengikat mereka yang membuatnya seperti undang-undang (seolah-olah seperti sebuah undangundang yang harus dipatuhi oleh kedua belah pihak yang berjanji, bukan oleh orang lain), atau dengan perkataan lain, dalam soal perjanjian, kita diperbolehkan membuat undang-undang bagi kita sendiri. Asas pacta sunt servanda merupakan asas yang mempertegas bahwa hakim atau pihak ketiga harus menghormati subtansi kontrak yang dibuat oleh para pihak layaknya sebuah Undang-Undang. Mereka tidak diperbolehkann melakukan intervensi terhadap substansi kontrak yang dibuat oleh para pihak. ${ }^{22}$

Dari penjelasan di atas di dalam isi akta Akad Murabahah bil Wakalah PT. Bank BRI Syariah, Tbk terdapat irah-irah bahwa: apabila berdasarkan pertimbangan Bank, nilai dari barang-barang jaminan sebagaimana dimaksud dalam dokumentasi Jaminan tidak lagi cukup untuk menjamin pembayaran

${ }^{21}$ Muhammad Syaifudin, Hukum Kontrak, Mandar Maju, Bandung, 2012, hlm. 81

22 Ratna Artha Windari, Hukum Perjanjian, Graha Ilmu, Yogyakarta, 2014, hlm. 9 
kewajiban / hutang Musytari kepada Bank, maka atas permintaan pertama dari bank, Musytari wajib menambah barang jaminan lainnya yang disetujui bank.

Dalam isi akad tersebut dimana bank mengambil keputusan sepihak dan Musytari dengan posisi membutuhkan dana maka Musytari tersebut tetap menandatangani tanpa memikirkan dampak dari yang Musytari tandatangani tersebut. Akan tetapi jika pihak Musytari menyepakati ketentuan tersebut dan sudah menyetujui baik hak maupun tanggung jawab setelah perjanjian ini di tandatangani maka secara hukum perjanjian tersebut sah. Hal tersebut sesuai dengan ketentuan Asas pacta sunt servanda dimana semua perjanjian yang dibuat secara sah berlaku sebagai Undang-Undang bagi yang mereka yang membuatnya dan harus dijalankan serta di taati ketentuan perjanjian tersebut.

Akan tetapi dalam kasus ini bank seharusnya juga sudah mempertimbangkan berbagai prinsip-prinsip dalam perbankan, menurut penulis pihak bank tidak memperhatikan salah satu dari prinsip, yaitu prinsip kehatihatian untuk melindungi pihaknya. Prinsip kehati-hatian (prudent banking principle) adalah suatu asas atau prinsip yang menyatakan bahwa dalam menjalankan fungsi dan kegiatan usahanya wajib bersikap hati-hati (prudent) dalam rangka melindungi dana masyarakat yang dipercayakan padanya. ${ }^{23}$

Berkenaan dengan perjanjian di atas mengenai akad Murabahah bil Wakalah, salah satu rukun dan syarat sahnya adanya akad tersebut yaitu harga barang, dalam hal ini harga barang harus diketahui secara jelas yaitu harga beli dan margin yang akan disepakati oleh kedua belah pihak. Dari ketentuan rukun tersebut sudah jelas mengenai harga sudah pasti maka pihak Bank seharusnya sudah pasti terhadap nilai jaminan yang di berikan oleh Musytari kepada pihak Bank. Pihak bank berdalih dimana jaminan yang sudah terpasang ternyata kurang dan harus menambah jaminan tersebut agar dapat mengakomodir harga barang tersebut, sedangkan dalam prinsip hukum Islam dimana harga barang sudah jelas dan pasti maka jaminanpun seharusnya pihak bank sudah mempertimbangkan berapa nilai jaminan yang harus di serahkan dari pihak Musytari kepada pihak bank itu sendiri. Namun kembali lagi pihak Musytari dalam posisi tersebut terbentur oleh perjanjian baku seperti yang di jelaskan di atas dimana perjanjian yang sudah di sepakati dan ditandatangani dan dibuat secara sah berlaku sebagai undang-undang.

Seharusnya bank juga memperhatikan suatu asas kebebasan berkontrak, dimana dengan asas kebebasan berkontrak ini, para pihak yang membuat dan mengadakan perjanjian diperbolehkan untuk menyusun dan membuat hlm. 18 .

${ }^{23}$ Rachmadi Usman, Aspek-aspek. Hukum Perbankan di Indonesia, Gramedia Pustaka Utama, Jakarta, 2001, 
kesepakatan atau perjanjian yang melahirkan kewajiban apa saja, selama dan sepanjang prestasi yang wajib dilakukan tersebut bukanlah sesuatu yang terlarang. ${ }^{24} \mathrm{Hal}$ ini seharusnya baik pihak bank maupun pihak Musytari bebas dalam menyusun isi dari perjanjian tersebut. Akan tetapi, pihak lawannya pada umumnya karena ketidaktahuannya, dan hanya menerima apa yang disodorkan, serta dalam kasus ini pihak Musytari sebagian besar berposisi dengan tingkan penawaran yang lemah. maka pemakaian perjanjian baku tersebut sedikit banyaknya telah menunjukan perkembangan yang sangat membahayakan kepentingan masyarakat, terlebih dengan mengingat bahwa awamnya masyarakat terhadap aspek hukum secara umum, dan khususnya pada aspek hukum perjanjian..$^{25}$

Salah satu Musytari mengatakan bahwa mereka melakukan Akad Murabahah bil Wakalah pada PT. Bank BRI Syariah, Tbk merasa aman dan sesuai ketentuan ajaran islam yang benar, dimana Musytari menyetujui semua keinginan yang di ajukan oleh pihak bank tanpa memikirkan dampak dari hal tersebut. ${ }^{26}$ Dari pernyataan tersebut jelas dimana Musytari masih minim akan pengetahuan hukum baik hak dan kewajiban serta dampak yang akan di peroleh apabila Musytari menandatangani akad tersebut. Serta pihak Musytari juga mengutarakan bahwa pihak Musytari tersebut tidak dilibatkan dalam menuangkan isi dari perjanjian tersebut, pilihan Musytari hanya diminta untuk menendatangani perjanjian tersebut.

Kedudukan para pihak menurut penulis, dimana pihak bank sebagai yang ekonominya kuat dan memiliki dana sedangkan pihak Musytari dengan ekonomi yang lemah, pihak Bank dari hal tersebut membuat akad tersebut sesuai keinginan bank tanpa memikirkan dampak dari pihak Musytari. Secara hukum perjanjian tersebut oleh pihak bank sudah ditulis sedemikian dengan adanya akta dan akad Murabahah bil Wakalah, namun pada pelaksanaanya baik dari pihak bank maupun Musytari masih kurang memahami akan pentingnya membuat perjanjian yang sesuai dengan hukum Islam dan sesuai asas dari perjanjian dengan tetap memperhatikan salah satunya kesetaraan dan keadilan. Sedangkan dari segi prinsip hukum seharusnya pihak bank membacakan dan memberi pilihan kepada pihak Musytari akan isi perjanjian tersebut, akan tetapi pihak bank dan Musytari tidak membaca dengan seksama klausul perjanjian yang berdampak dikemudian hari pada sah dan tidaknya perjanjian sehingga dapat berlaku mengikat, dan juga

\footnotetext{
${ }^{24}$ Kartini Muljadi \& Gunawan Widjaja, Op. Cit., hlm. 46.

${ }^{25} \mathrm{Ibid}, \mathrm{hlm} .13$.

26 Wawancara dengan Mustyari PT. Bank BRI Syariah, Tbk, Senin 17 Februari 2020 pukul 13.00 WIB.
} 
Musytari kurang tanggap akan hal yang seperti ini dengan hanya menganggap perjanjian tersebut saling menguntungkan atau adil dan setelah perjanjian tersebut ditanda tangani maka legalitasnya sah dihadapan hukum.

Jaminan diberikan untuk melindungi kepentingan bank untuk memperkecil risiko jika seandainya Musytari tidak mampu menyelesaikan semua kewajiban yang timbul dari utang atau kredit yang telah dikeluarkannya. Jika Musytari tidak mampu membayar utangnya maka bank dapat memaksakan pembayaran atas Taqsith (kredit) yang telah diberikannya tersebut. Namun dalam keadaan suatu perjanjian syariah pihak bank seharusnya mengetahui bagaimana syarat dan rukun yang harus mereka taati sesuai hukum Islam.

Pihak bank menganggap bahwa penambahan jaminan pada suatu akad Murabahah bil Wakalah sudah wajar dilakukan, sepanjang di perjanjian tersebut di sepakati oleh pihak Musytari, perjanjian tersebut sudah menjadi perinsip baku di bank yang dibuat oleh pihak bank, Pihak bank menurut penulis seharusnya sudah pasti dan memperhitungkan semua isi dari perjanjian tanpa harus menambah jaminan dikemudian hari. Namun apabila Musytari menyetujui perjanjian tersebut maka secara asas perjanjian yang berlaku perjanjian tersebut sah dan legal secara hukum. Banyak dari pihak Musytari tidak mengetahui dan paham bagaimana dampak dari perjanjian tersebut maka dapat mengakibatkan Musytari rugi dan tidak sesuai apa yang diinginkan oleh pihak Musytari itu sendiri karna sudah percaya terhadap perjanjian yang dibuat oleh pihak bank dan perjanjian tersebut legal secara hukum.

Dengan demikian, diharapkan agar perjanjian yang dibuat oleh perbankan syariah memperhatikan dengan cermat atas peraturan-peraturan yang terkait dengan perjanjian yang dituangkan dalam setiap produknya, baik dari segi prinsip syariah dan juga peraturan hukum penunjangnya. Dan bersikap lebih adil dalam menuangkan isi perjanjian baik pihak bank maupun pihak Musytari. Tujuannya dari perjanjian seharusnya adalah agar perjanjian tersebut tidak akan menimbulkan hal-hal yang dapat merugikan bagi kedua belah pihak.

\section{Peranan Notaris dalam Menjamin Penerapan Asas Taswiyah Pada Akad Pembiayaan Murabahah Bil Wakalah PT. Bank Bri Syariah, Tbk}

Asas taswiyah merupakan suatu asas kesetaraan antara pihak yang membuat suatu perjanjian, Kompilasi Hukum Ekonomi Syariah menyebutkan bahwa akad harus dilakukan berdasarkan asas taswiyah yaitu para pihak dalam setiap akad memiliki kedudukan yang setara dan mempunyai hak dan kewajiban yang seimbang. ${ }^{27}$ Hal tersebut pihak Musytari dan pihak bank mempunyai kedudukan

${ }^{27}$ Pasal 21 huruf f Kompilasi Hukum Ekonomi Syariah 
yang sama, sehingga dalam menentukan segala sesuatunya mengenai isi perjanjian, para pihak tidak ada yang merasa lebih tinggi kedudukanya.

Unsur kesetaraan sebagai salah satu asas dalam akad pada Bank Syariah menunjukkan bahwa posisi salah satu pihak yang lebih unggul dibanding pihak lainnya tidak menyebabkan pihak yang lebih tinggi tersebut bisa memaksakan suatu ketentuan yang memberatkan pihak lainnya. Akad baku dengan pencantuman klausula eksonerasi, tidak boleh terjadi di Bank Syariah ketika asas kesetaraan tidak diimplementasikan. Dengan dikeluarkannya Undang-Undang Nomor 10 Tahun 1998 tentang Perubahan Atas Undang-undang Nomor 7 Tahun 1992 tentang Perbankan, dapat disimpulkan bahwa sistem Perbankan Syariah dikembangkan dengan tujuan membuka peluang Pembiayaan bagi pengembangan usaha berdasarkan prinsip jual-beli atau Murabahah. Dalam prinsip ini, konsep yang diterapkan adalah hubungan antara Bank Syariah dan Musytari yang harmonis. ${ }^{28}$

Herlien Budiono mengungkapkan, mengenai asas kesetaraan dengan merujuk pada uraian Moh Koesnoe tentang asas laras (harmoni) dalam hukum adat Indonesia, bahwa asas laras berkenaan dengan persoalan bagaimana memuaskan kebutuhan yang estetis dalarn masyarakat. Asas ini memberikan jawaban atas suatu persoalan sehingga penyelesaiannya itu dianggap memuaskan dari ukuran kebutuhan dan perasaan hukum dan moral. Maksudnya adalah segala sesuatu telah kembali seperti semula (sebelum sengketa muncul dan mengganggu keseimbangan masyarakat). ${ }^{29}$

Unsur kesetaraan (taswiyah) sebagai salah satu asas dalam akad di bank syariah menunjukan tidak ada hubungan salah satu pihak berada dalam posisi yang lebih unggul dibanding pihak yang lain sehingga seolah bisa memaksakan suatu ketentuan yang menguntungkan. Standar kontrak dengan pencantuman klausula eksonerasi, tidak boleh terjadi di Bank Syariah ketika asas kesetaraan diimplementasikan. Dengan dikeluarkannya Undang-Undang Nomor 10 Tahun 1998 tentang Perubahan Atas Undang-Undang Nomor 7 Tahun 1992 tentang Perbankan, menyebutkan bahwa fungsi perbankan sebagai penghimpun dan penyalur dana masyarakat, serta tujuan perbankan untuk menunjang pembangunan nasional. Dapat disimpulkan bahwa sistem perbankan syariah dikembangkan dengan tujuan membuka peluang pembiayaan bagi

\footnotetext{
${ }^{28}$ Wirdyaningsih, Bank dan Asuransz. Islam Di Indonesia, Pranata Media, Jakarta, 2005, hlm. 65. hlm. 510 .

${ }^{29}$ Herlin Budiono, Asas Keseimbangan Bagi Hukum Perjanjian Indonesia, Citra Aditya Bakti, Bandung 2006,
} 
pengembangan usaha berdasarkan prinsip kemitraan. ${ }^{30}$ Asas tersebut sudah jelas dimana suatu perjanjian syariah harus memenuhi unsul keadilan dan kesetaraan dalam melakukan suatu perbuatan akad.

Penerapan asas kesetaraan pada suatu perjanjian berfungsi untuk menjamin kesamaan kedudukan para pihak, yaitu saat sebelum terjadinya akad atau proses penyusunan akad, para pihak mempunyai porsi dan ide tawar yang sama, dalam menentukan isi akad, para pihak mempunyai hak dan kewajiban yang setara seperti yang disebutkan dalam peraturan perundang-undang dan Fatwa Dewan Syariah Nasional, serta kedudukan yang seimbang dalam proses penyelesaian sengketa apabila terjadi sengketa.

Dalam prinsip ini, konsep yang diterapkan adalah hubungan antar investor yang harmonis. Prinsip kemitraan dan kesetaraan tersebut harus saling terjaga. Hal ini karena dalam akad tersebut Bank hakikatnya melakukan kerjasama dengan Musytari, dimana masing-masing pihak memberikan kontribusi dana dengan kesepakatan bahwa keuntungan dan resiko akan ditanggung bersama sesuai kesepakatan. ${ }^{31}$ Dasar dari semua akad tersebut yaitu perjanjian dimana perjanjian tersebut sangat pokon baik isi maupun maksud dan tujuan perjanjian.

Perjanjian secara lebih rinci didefinisikan oleh Subekti yang menyatakan bahwa perjanjian adalah suatu peristiwa dimana seseorang berjanji kepada seseorang yang lain atau dimana dua orang itu saling berjanji untuk melaksanakan suatu hal.32 Prinsip syariah yang digunakan berkaitan dengan perjanjian yang terdapat pada fatwa diatur secara tersendiri pada tiap produk dan jasa yang terdapat pada fatwa diatur secara tersendiri pada tiap produk dan jasa yang terdapat pada perbankkan syariah. Saat ini, kebanyakan perjanjian yang terdapat pada perbankkan syariah dibuat secara baku dimana beberapa klausul yang terdapat pada perjanjian-perjanjian tersebut dapat memberatkan pada salah satu pihak saja. Memberatkan salah satu pihak yang dimaksud disini pihak yang mempersiapkan perjanjian baku tersebut yaitu pihak bank sedangkan kedudukan yang diberatkan pada hal tersebut yaitu pihak Musytari. ${ }^{33}$

Bahkan Pitlo menyebutkan perjanjian baku sebagai perjanjian paksaan karena sudah tidak ada lagi kebebasan sehingga pihak yang lemah terpaksa menerimanya sebab tidak mampu berbuat lain. Pendapat dari Stein juga hampir sama dengan Pitlo, menurut Stein dasar berlakunya perjanjian baku adalah de

\footnotetext{
${ }^{30}$ Destri Budi Nugraheni, “Asas Kesetaraan Dalam Akad Pembiayaan Musyarakah pada Bank Syariah di Yogyakarta”, Jurnal Mimbar Hukum, Vol. 22 No. 1, 2010, hlm. 4.

31 Ibid.

${ }^{32}$ R. Subekti, Hukum Perjanjian, Internasa, Bandung, 1987, hlm. 1.

33 Sutan Remi Sjahdeini, Kebebasan Berkontrak dan Perlindungan Yang Seimbang Bagi Para Pibak Dalam Perjanjian Kredit di Bank di Indonesia, Institut Bankir Indonesia, Jakarta, 1993, hlm. 71.
} 
fictie van will of vetrouwen sehingga kebebasan berkehendak yang sungguhsungguh tidak ada pada para pihak, khususnya debitur. ${ }^{34}$

Pada umunnya syarat perjanjian tersebut dibuat secara tertulis oleh bank hanya untuk melindungi kepentingannya sendiri tanpa mempertimbangkan kepentingan Musytari, sehingga terlihat lebih menguntungkan bagi pihak yang mempersiapkan perbuatannya dan sering terjadi bank mengalihkan kewajibankewajiban yang seharusnya menjadi tanggung jawabnya kepada Musytari. Dapat dikatakan bahwa materi klausula baku bukanlah hasil suatu kesepakatan melainkan hasil pemaksaan kepada pihak lain untuk menerima atau tidak menerima sama sekali sehingga dapat menimbulkan suatu kondisi yang tidak seimbang antara bank dengan Musytari. 35

Ciri perjanjian baku sebagai berikut: (1) Isinya ditetapkan sepihak yang posisinya lebih kuat; (2) Masyarakat dalam hal ini debitor tidak ikut bersamasama menentukan isi perjanjian; (3) Terdorong oleh kebutuhan, debitor terpaksa menerima perjanjian itu; (4) Dipersiapkan lebih dahulu secara massal dan kolektif. 36

Melihat dari penjelasan di atas, mayoritas bentuk perjanjian perbankan Syariah adalah berbentuk perjanjian standar atau perjanjian baku itu sendiri. Dalam perjanjian semua standar syarat-syarat dan ketentuan ditentukan sepihak oleh pihak bank. Pihak Musytari tidak memiliki posisi tawar (bargaining position) yang menguntungkan atau tidak merundingkan isi dari perjanjian yang akan mereka tandatangani. Beberapa bentuk perjanjian baku yang sangat banyak digunakan dalam bisnis perbankan terutama perbankkan syariah yaitu akad perjanjian murabahah bil wakalah, walaupun di dalam peraturan perUndangUndangan yang mengatur secara khusus tentang perbankan tidak ditemukan adanya pengaturan yang secara tegas dapat dijadikan dasar hukum dalam memberikan jaminan kepastian perlindungan terhadap Musytari dalam pelaksanaan perjanjian baku tersebut dianggap sebagai perjanjian yang lazimnya dilakukan melalui perjanjian yang biasa pihak bank buat.

Oleh karena itu, dalam kontrak baku kebebasan untuk melakukan kontrak serta pemberian kesepakatan terhadap kontrak tersebut tidak dilakukan sebebas dengan perjanjian yang dilakukan secara langsung dengan melibatkan para pihak

34 Alamsyah, "Klausula Eksemsi Dalam Kontrak Baku Syariah", http://www.papalembang.go.id $/$ index.php?option $=$ com_content\&view $=$ article\&id=161:klausula-eksemsi-dalam-kontrak-bakusyariah-oleh--alamsyah-303-\&catid=135:artikel\&Itemid=182., diakses tanggal 26 Februari 2020.

35 H.P Panggabean, Praktik Standard Contract (Perjanjian Baku) dalam Perjanjian Kredit Perbankan, Alumni, Bandung, 2012, hlm. 20.

${ }^{6}$ Mariam Darus Badrulzaman, Kompilasi Hukum Perikatan, Citra Aditya Bakti, Bandung, 2001, hlm. 69. 
dalam menegosiasikan klausul perjanjian, terdapat berbagai pendapat mengenai kedudukan kontrak baku dalam hukum perjanjian. Adapun pendapat-pendapat tersebut adalah sebagai berikut, Pertama, Sluijter mengatakan bahwa kontrak baku bukan merupakan perjanjian, sebab kedudukan pengusaha dalam perjanjian itu adalah seperti pembentuk undang-undang swasta (legio particuliere wetgever). Syarat-syarat yang ditentukan pengusaha dalam perjanjian itu adalah undangundang, bukan perjanjian.

Kedua, Pitlo menggolongkan kontrak baku sebagai perjanjian paksa (dwang contract), yang walaupun secara teoretis yuridis, kontrak baku ini tidak memenuh ketentuan undang-undang dan oleh beberapa ahli hukum ditolak, namun kenyataannya kebutuhan masyarakat berjalan dalarn arah yang berlawanan dengan keinginan hukum. Ketiga, Stein mencoba memecahkan masalah ini dengan mengemukakan pendapat bahwa kontrak baku dapat diterima sebagai perjanjian, berdasarkan fiksi adanya kemauan dan kepercayaan (Fictie van wil en vertrouwen) yang membangkitkan kepercayaan bahwa para pihak mengikatkan diri pada perjanjian itu. Jika Musytari menerima dokumen perjanjian itu, berarti ia secara sukarela setuju pada isi perjanjian tersebut.

Keempat, Aser Rutten mengatakan, bahwa setiap orang yang menandatangani perjanjian, bertanggung gugat pada isi dan apa yang ditandatanganinya. Jika ada orang yang membubuhkan tanda tangan pada formulir perjanjian baku, tanda tangan itu akan membangkitkan kepercayaan bahwa yang bertanda tangan mengetahui dan menghendaki isi formulir yang ditandatangani. Tidak mungkin seorang menandatangani apa yang tidak diketahui isinya. Kelima, Hondius dalam disertasinya mempertahankan, bahwa perjanjian baku mempunyai kekuatan mengikat berdasarkan "kebiasaan" (gebruik) yang berlaku di lingkungan masyarakat dan lalu lintas perdagangan. ${ }^{37}$

Berdasarkan berbagai pendapat di atas, penulis berpendapat bahwa kontrak baku tetap merupakan perjanjian yang mengikat para pihak yang menandatanganinya, walaupun dalam hal tersebut bahwa klausul yang terdapat dalam kontrak baku banyak mengalihkan beban tanggung gugat dari pihak perancang atau pihak bank, perjanjian baku kepada pihak lawannya atau Musytari, namun setiap kerugian yang timbul di kemudian hari akan tetap ditanggung oleh para pihak yang harus bertanggung gugat berdasarkan klausul perjanjian tersebut serta perjanjian tersebut secara hukum sudah sah atau legalitasnya sah dimana pihak nasabah dan pihak Musytari sepakat dalam menandatangani perjanjian tersebut.

${ }^{37}$ Ahmadi Miru, Hukum Kontrak dnn Perancangan Kontrak, Rajawali Pers, Jakarta, 2011, hlm. 43. 
Apabila melihat kembali pada asas-asas dari perjanjian menurut Hukum Islam, maka dapat diketahui bahwa pada intinya perjanjian akad Murabahah bil Wakalah pada akad yang dilaksanakan PT. Bank BRI Syariah, Tbk tidak adanya Asas taswiyah. Asas tersebut merupakan suatu asas kesetaraan antara pihak yang membuat suatu perjanjian. Pada asas kebebasan kesetaraan, para pihak yang melakukan akad harus memiliki dasar kesetaraan antara masing-masing pihak, tidak boleh ada tekanan, ketidak adilan, paksaan, dan penipuan, namun dalam legalitas perjanjian tersebut sah di hadapan hukum.

Dari perjanjian tersebut pihak PT. Bank BRI Syariah, Tbk juga melibatkan notaris, dengan harapan lebih kuat dalam pembuktiannya, dengan adanya keterlibatan notaris, para pihak seharusya lebih aman dan terjamin kepastian di hadapan hukum, baik hukum positif ataupun hukum islam itu sendiri. Kewenangan notaris dalam menjalankan jabatanya sebagai pejabat umum dapat dilihat dalam Pasal 15 ayat (1) Undang-Undang Jabatan Notaris. Notaris berwenang membuat akta autentik mengenai semua perbuatan, perjanjian, dan penetapan yang diharuskan oleh perUndang-Undangan dan/atau yang dikehendaki oleh yang berkepentingan untuk dinyatakan dalam akta autentik. Notaris menjamin kepastian tanggal pembuatan akta, penyimpanan akta, memberikan grosse, salinan dan kutipan akta. 38

Pasal 15 ayat (2) Undang-Undang Jabatan Notaris juga menjelaskan kewenangan Notaris selain yang termasuk di dalam Pasal 15 ayat (1) UndangUndang Jabatan Notaris yang menyebutkan bahwa selain kewenangan sebagaimana dimaksud pada ayat (1), Notaris berwenang pula untuk mengesahkan tanda tangan dan menetapkan kepastian tanggal surat di bawah tangan dengan mendaftar dalam buku khusus; membukukan surat dibawah tangan dengan mendaftar dalam buku khusus; membuat salinan dari asli surat dibawah tangan berupa salinan yang memuat usaian sebagaimana ditulis dan digambarkan dalam surat yang bersangkutan; melakukan pengesahan kecocokan fotocopy dengan surat aslinya; memberikan penyuluhan hukum sehubungan dengan pembuatan akta; membuat akta yang berkaitan dengan pertanahan; membuat akta risalah lelang. ${ }^{39}$

Penyuluhan hukum merupakan salah satu sosialisasi untuk menggambarkan bagaimana itu keadilan, Hukum nasional tidak bisa menjamin

\footnotetext{
38 Guntur Iskandar, "Pembuktian Akta Di bawah Tangan yang Disahkan dan Dibukukan Oleh Notaris", Jurnal Yustisia Universitas Andalas, Vol. 22, No. 1, 2013, hlm. 54

39 Zulheriyanto, "Pembaharuan Surat Kuasa Membebankan Hak Tanggungan (SKMHT) Dalam Pemasangan Hak Tanggungan: Studi Kasus di Kota Bukittinggi”, Jurnal Yustisia Universitas Andalas, Vol. 01, No. 1, 2013, hlm. 108
} 
terwujudnya keadilan itu. ${ }^{40}$ Kelsey dan Herane mengemukakan bahwa filsafat penyuluhan adalah bekerja sama dengan masyarakat agar mereka dapat meningkatkan harkatnya sebagai manusia. Dari pendapat tersebut terkandung pengertian pertama, penyuluhan harus bekerja sama dengan masyarakat. Kehadiran penyuluh bukan sebagai penentu atau pemaksa, tetapi ia harus mampu menciptakan suasana dialogis dengan masyarakat dan mampu menumbuhkan, menggerakan, serta memelihara partisipasi masyarakat. Kedua, penyuluhan tidak menciptakan ketergantungan tetapi harus mampu mendorong semakin terciptanya kreativitas dan kemandirian masyarakat agas semakin memiliki kemampuan untuk berswakarsa swadaya, swadana, dan swakelola bagi terselenggaranya kegiatan-kegiatan guna tercapainya tujuan, harapan, dan keinginan-keinginan masyarakat sasaranya. Ketiga, penyuluhan yang dilakukan harus selalu mengacu kepada terwujudnya kesejahteraan ekonomi masyarakat dan peningkatan harkatnya sebagai manusia. ${ }^{41}$

Notaris dalam memberikan penyuluhan hukum dapat disamakan dengan memberikan suatu nasihat hukum karena dalam memberikan suatu penyuluhan hukum maupun nasihat hukum baik itu hak, tanggung jawab serta dampak yang akan di peroleh setelah melakukan akad perjanjian tersebut. Notaris dalam hal ini memberikan suatu petunjuk atau penjelasan dalam bidang hukum yang sedang dihadapi atau dibutuhkan oleh para penghadap. Pemberian penyuluhan hukum oleh notaris dapat mempengaruhi para pihak dalam menentukan pilihan untuk menentukan tindakan hukumnya. Mengenai penerapan asas kebebasan berkontrak sepenuhnya tergantung pada para pihak untuk menentukan pilihannya, sedangkan notaris menjaga rambu-rambu hukumnya. ${ }^{42}$

Pihak bank mengatakan bahwa perjanjian tersebut dibuat sesuai standar dari bank tersebut, serta membuat dari tahun demi tahun seperti tersebut isi dan maksud dari akta yang akan di tandatangani oleh pihak bank dan pihak Musytari. ${ }^{43}$ Pihak Musytari juga menyatakan bahwa perjanjian tersebut sudah ada dan pihak Musytari hanya untuk menandatangani saja tanpa ada pertanyaan yang memberatkan atau tidak. ${ }^{44}$ Notaris sebagai pejabat umum seharusnya memberi penyuluhan hukum terkait dampak, kewajiban serta hak yang di dapat setelah perjanjian itu di tandatangani oleh para pihak serta menyadarkan mengenai isi

40 Sudijito, "Critical Legal Studies (CLS) dan Hukum Progresif sebagai Alternatif dalam Reformasi Hukum Nasional dan Perubahan Kurikulum Pendidikan Hukum”, Jurnal Ultimatum Sekolah Tinggi Hukum Islam, Vol. 2, 2018, hlm. 3

${ }^{41}$ Nurul Huda, "Penyuluhan Hukum dan Hak Asasi Manusia Sebuah Ilmu: Kajian Filsafat Ilmu", http://www.rudyct.com/PPS702-ipb/04212/nurul huda.htm, diakses tanggal 02 Maret 2020.

42 Rusdianto Sesung, Op. Cit.,, hlm. 63.

43 Wawancara pegawai PT. Bank BRI Syariah, Tbk, Kamis 13 Februari 2020 pukul 10.00 WIB.

${ }^{44}$ Wawancara Mustyari PT. Bank BRI Syariah, Tbk, Senin 18 Februari 2020 pukul 13.00 WIB. 
perjanjian yang akan di tandatangani. Hak dan kewajiban tersebut wajib dan harus di taati oleh semua pihak baik pihak Musytari maupun pihak bank itu sendiri.

Pada pembuatan akta Murabahah bil Wakalah yang dibuat oleh PT. Bank BRI Syariah, Tbk peranan dari notaris dimana notaris sebagai pejabat umum seharusnya memberi arahan dan penyuluhan hukum yang baik untuk kedua pihak. Penyuluhan tersebut harus menerangkan bagaimana kewajiban dan hak yang harus di peroleh baik pihak bank maupun pihak Musytari. Dimana asas taswiyah seharusnya dituangkan dalam perjanjian para pihak dalam setiap akad murabahah bil wakalah.

Peranan Notaris dalam semua aspek kewenangannya terutama dalam penyuluhan hukum dalam pembuatan suatu perjanjian sangat dibutuhkan dimana para pihak seharusnya terlindungi hak serta kewajibanya. Terlebih pihak Musytari yang sering terdesak akan perjanjian yang dibuat oleh pihak bank. Wajib bagi notaris untuk memberikan penyuluhan hukum dalam pembuatan perjanjian, semua pihak harus terlindungi terlebih dari pihak Musytari yang wajib dilindungi.

\section{Penutup}

Berdasarkan pembahasan dan analisis terhadap permasalahan, kesimpulan yang dapat diambil adalah sebagai berikut: Pertama, perjanjian Murabahah bil Wakalah yang dibuat pihak bank dengan Musytari dengan posisi Musytari membutuhkan dana maka Musytari tersebut tetap menandatangani tanpa memikirkan dampak dari yang Musytari tandatangani. Akan tetapi jika pihak Musytari menyepakati ketentuan tersebut dan sudah menyetujui baik hak maupun tanggung jawab setelah perjanjian ini di tandatangani maka secara hukum perjanjian tersebut sah/legal. Hal tersebut sesuai dengan ketentuan Asas pacta sunt servanda dimana semua perjanjian yang dibuat secara sepakat serta sah, maka berlaku sebagai Undang-Undang bagi yang mereka yang membuatnya dan harus dijalankan serta di taati ketentuan perjanjian tersebut. Asas ini disimpulkan dalam Pasal 1338 ayat (1) KUHPerdata, pada pasal tersebut menyatakan bahwa semua perjanjian yang dibuat secara sah berlaku sebagai undang-undang bagi yang mereka yang membuatnya. Dengan menekankan pada perkataan semua, maka pasal tersebut berisikan suatu pernyataan kepada masyarakat bahwa kita diperbolehkan membuat perjanjian yang berupa dan berisi apa saja atau tentang apa saja dan perjanjian itu akan mengikat mereka yang membuatnya seperti undang-undang yang harus dipatuhi oleh kedua belah pihak yang membuat 
perjanjian tersebut. Kedua, peranan Notaris terhadap akta Murabahah bil Wakalah dalam kasus tersebut dimana notaris wajib untuk melaksanakan penyuluhan hukum yang dalam hal ini, klausula yang mengharuskan musytari untuk menambah objek jaminan berdasarkan pertimbangan bank pada akad murabahah bil wakalah Untuk memberikan pemahaman tentang akibat hukum yang akan di derita oleh Musytari yaitu harus menambah objek jaminan apabila di kemudian hari menurut dasar pertimbangan pihak Bank mengharuskan demikian. Dengan notaris telah memberikan penyuluhan hukum yang demikian terhadap Musytari, maka diharapkan kalau terjadi sesungguhnya dikemudian hari harus menambah objek jaminan, Musytari sudah bisa memahaminya dengan baik dan tidak dirasa memberatkan baginya.

Adapun saran yang dapat penulis sampaikan melalui penelitian ini sebagai berikut: Pertama, musytari lebih teliti dalam melakukan tindakan hukum berupa perjanjian murabahah bil wakalah terutama memastikan isi perjanjian sesuai yang Musytari inginkan dan mengetahui sejelas-jelasnya dampak dari perjanjian serta tidak memberatkan dikemudian hari. Kedua, pihak bank dalam melakukan perbuatan hukum lebih memperhatikan terhadap aturan-aturan hukum yang berlaku dan tidak serta merta mencari keuntungan dengan merugikan berbagai pihak. Ketiga, Notaris dalam melaksanakan kewajiban dan wewenangnya harus dengan memberikan penyuluhan hukum terkait akta murabahah bil wakalah kepada musytari, agar pihak musytari memahami jelas mengenai dampak yang akan di derita oleh pihak musytari terhadap akta perjanjian yang disepakatinya.

\section{Daftar Pustaka}

\section{Buku}

Anshori, Abdul Ghofar, Pokok-pokok Hukum Perjanjian Islam di Indonesia, Citra Media, Yogyakarta, 2006.

Ascarya, Akad dan Produk Bank Syariah, Raja Grafindo Persada, Jakarta, 2008.

Asiyah, Binti Nur, Manajemen Pembiayaan Bank Syariah, Teras, Yogyakarta, 2014.

Badrulzaman, Mariam Darus, Kompilasi Hukum Perikatan, PT. Citra Aditya Bakti, Bandung, 2001.

Budiono, Herlin, Asas Keseimbangan Bagi Hukum Perjanjian Indonesia, Citra Aditya Bakti, Bandung, 2006.

Ghazaly, Abdul Rahman, Fiqh Muamalat, Kencana, Jakarta, 2010.

Idris, Figh Menurut Madzhab Syafi'i, Widjaya, Jakarta, 1969.

Miru, Ahmadi, Hukum Kontrak dnn Perancangan Kontrak, Rajawali Pers, Jakarta, 2011.

Muhammad, Abdulkadir, Hukum Perdata Indonesia, Cetakan Ke-III., Citra Aditya Bakti, Bandung, 2000. 
Muljadi, Kartini dan Gunawan Widjaja, Perikatan yang Lahir dari Perjanjian, RajaGrafindo Persada, Jakarta, 2004.

Perwataatmadja, Karnaen dan Muhammad Syafi'i Antonio, Apa dan Bagaimana Bank Islam, Yogyakarta, Dana Bhakti Wakaf, 1992

Panggabean, H.P., Praktik Standard Contract (Perjanjian Baku) dalam Perjanjian Kredit Perbankan, P.T. Alumni, Bandung, 2012

Sesung, Rusdianto, Hukum dan Politik Hukum Jabatan Notaris, R.A. De Rozarie, Surabaya, 2017.

Sjahdeini, Sultan Remi, Kebebasan Berkontrak dan Perlindungan Yang Seimbang Bagi Para Pihak Dalam Perjanjian Kredit di Bank di Indonesia, Institut Bankir Indonesia, Jakarta, 1993.

Subekti, R., Hukum Perjanjian, Intermasa, Bandung, 1987.

Subekti, R. dan R. Tjitrosudibio. Kitab Undang-undang Hukum Perdata, Pradnya Paramita, Jakarta, 2006.

Syaifudin, Muhammad, Hukum Kontrak, CV Mandar Maju, Bandung, 2012.

Usman, Rachmadi, Aspek-aspek Hukum Perbankan di Indonesia, PT Gramedia Pustaka Utama, Jakarta, 2001.

Windari, Ratna Artha, Hukum Perjanjian, Graha Ilmu, Yogyakarta, 2014.

Wirdyaningsih, Bank dan Asuransz Islam Di Indonesia, Pranata Media, Jakarta, 2005.

Jurnal

Destri Budi Nugraheni, “Asas Kesetaraan Dalam Akad Pembiayaan Musyarakah pada Bank Syariah di Yogyakarta”, Jurnal Mimbar Hukum, Vol. 22, No. 1, 2010.

Iskandar, Guntur, "Pembuktian Akta di Bawah Tangan yang Disahkan dan Dibukukan oleh Notaris", Jurnal Yustisia Universitas Andalas, Vol. 22, No. 2013.

Simanjuntak, Ricardo, "Akibat dan Tindakan-tindakan Hukum terhadap Pencantuman Klausula Baku Dalam Polis Asuransi yang Bertentangan dengan Pasal 18 Undang-Undang Nomor 8 Tahun 1999 tentang Perlindungan Konsumen", Jurnal Hukum Bisnis, Vol.22, No. 22003.

Sudijito, "Critical Legal Stidies (CLS) dan Hukum Progresif sebagai Alternatif dalam Reformasi Hukum Nasional dan Perubahan Kurikulum Pendidikan Hukum", Jurnal Ultimatum Sekolah Tinggi Hukum Islam, Vol. 2, 2018.

Zulheriyanto, "Pembaharuan Surat Kuasa Membebankan Hak Tanggungan (SKMHT) Dalam Pemasangan Hak Tanggungan: Studi Kasus di Kota Bukittinggi", Jurnal Yustisia Universitas Andalas, Vol. 01, No. 1, 2013.

\section{Makalah}

Khairandy, Ridwan, "Keabsahan Perjanjian Standar Pasca Berlakunya UndangUndang Perlindungan Konsumen", Makalah, Yogyakarta, 2007. 


\section{Internet}

Alamsyah, "Klausula Eksemsi Dalam Kontrak Baku Syariah", http://www.papalembang.go.id/index.php?option=com_content\&view=article\&id=161: klausula-eksemsi-dalam-kontrak-baku-syariah-oleh--alamsyah-303\&catid=135:artikel\&Itemid=182., diakses tanggal 26 Februari 2020.

Nurul Huda, "Penyuluhan Hukum dan Hak Asasi Manusia Sebuah Ilmu: Kajian Filsafat Ilmu", http://www.rudyct.com/PPS702-ipb/04212/nurul_ huda.htm, diakses tanggal 02 Maret 2020

\section{Peraturan Perundang-Undangan}

Kitab Undang-Undang Hukum Perdata

Kompilasi Hukum Ekonomi Syariah 